\title{
PEMBINAAN DAN PENGEMBANGAN PTK
}

\author{
Resky Gerhana Hidayatullah \\ Universitas Negeri Padang \\ Indonesia \\ E-mail : gerhanaresky@gmail.com
}

\begin{abstract}
Guidance or development of educational staff is an effort to empower, advance and improve the work productivity of every teaching staff that exists at all levels of organizational management and levels of education (schools). The purpose of this coaching activity is the growth of the ability of each educational staff which includes scientific growth, insight into his thinking, attitude towards his work and skills in carrying out his daily tasks so that work productivity can be increased. guidance and career paths of educational staff are adjusted to the categories of each type of teaching staff itself. Even so, it is possible for someone's career to travel to the top of his career. In an effort to develop this educational staff, the role and commitment of the leadership is needed. Because not infrequently the
\end{abstract}

Keywords: Coaching, development, education personnel

\section{PENDAHULUAN}

Menurut Purwant (2007) Pembinaan atau pengembangan tenaga kependidikan merupakan usaha mendaya-gunakan, memajukan dan meningkatkan produktivitas kerja setiap tenaga kependidikan yang ada di seluruh tingkatan manajemen organisasi dan jenjang pendidikan (sekolah). Tujuan dari kegiatan pembinaan ini adalah tumbuhnya kemampuan setiap tenaga kependidikan yang meliputi pertumbuhan keilmuannya, wawasan berpikirnya, sikap terhadap pekerjaannya dan keterampilan dalam pelaksanaan tugasnya sehari-hari sehingga produktivitas kerja dapat ditingkatkan.

Suatu program pembinaan tenaga kependidikan biasanya diselenggarakan atas asumsi adanya berbagai kekurangan dilihat dan tuntutan organisasi, atau karena adanya kehendak dan kebutuhan untuk tumbuh dan berkembang dikalangan tenaga kependidikan itu sendiri.

Kemendikbud (2012) Beberapa prinsip yang patut diperhatikan dalam penyelenggaraan pembinaan tenaga kependidikan ini yaitu; development activities are hampered because there is no commitment and leadership to want to develop its staff. Thus the need for staff development is always an important agenda that can be carried out cooperatively between the leadership and the parties they lead. The method used in making this scientific article is a qualitative method, where as the object of study is a national journal and a book as a reference. In staffing administration it is more focused on teachers as civil servants. Public servants are those who, after fulfilling the conditions specified in the applicable legislation, are appointed by authorized officials and are entrusted with duties in a state office or accompanied by other State tasks determined based on applicable laws.

1. Pembinaan tenaga kependidikan patut dilakukan untuk semua jenis tenaga pendidikan baik untuk tenaga structural, tenaga fungsional maupun tenaga teknis penyelenggara pendidikan.

2. Pembinaan tenaga kependidikan berorientasi pada perubahan tingkah laku dalam rangka peningkatan kemampuan professional dan atau teknis untuk pelaksanaan tugas sehari-hari sesuai dengan posisinya masing-masing.

3. Pembinaan tenaga kependidikan dilaksanakan untuk mendorong meningkatnya kontribusi setiap individu terhadap organisasi pendidikan atau sistem sekolah; dan menyediakan bentuk-bentuk penghargaan, kesejahteraan dan insentif sebagai imbalannya guna menjamin terpenuhinya secara optimal kebutuhan social ekonomis maupun kebutuhan soSial-psikologi.

4. Pembinaan tenaga kependidikan dirintis dan diarahkan untuk mendidik dan melatih seseorang sebelum maupun sesudah menduduki jabatan/posisi, baik karena kebutuhan-kebutuhan yang berorientasi terhadap lowongan jabatan/posisi di masa yang kan datang. 
5. Pembinaan tenaga kependidikan sebenarnya dirancang untuk memenuhi tuntutan pertumbuhan dalam jabatan, pengembangan profesi, pemecahan masalah, kegiatan-kegiatan remedial, pemeliharaan motivasi kerja dan ketahanan organisasi pendidikan.

Menyangkut pembinaan dan jenjang karir tenaga kependidikan disesuaikan dengan kategori masingmasing jenis tenaga kependidikan itu sendiri. Meskipun demikian, dapat saja berjalan karir seseorang menempuh puncak karirnya. Dalam upaya pengembangan tenaga kependidikan ini, peran dan komitmen pimpinan sangat diperlukan. Karena tidak jarang aktivitas pengembangan tersebut terhambat karena tidak adanya komitmen dan pimpinan untuk mau mengembangkan stafnya. Dengan demikian kebutuhan pengembangan staf senantiasa menjadi agenda penting yang dapat dijalankan secara kooperatif antara pimpinan dengan pihak yang dipimpinnya.

\section{METODE PENULISAN}

Metode yang digunakan dalam pembuatan artikel ilmiah ini adalah metode kualitatif, dimana sebagai objek kajiannya merupakan jurnal nasional dan buku sebagai acuannya.

\section{Kajian Teori dan Pembahasan}

\section{A. Kenaikan Pangkat PTK}

Setiap personil berhak memperoleh kenaikan pangkat,apabila telah memenuhi persyaratan yang diperlukan untuk kenaikan pangkat itu .kenaikan pangkat bukan saja sebagai hak yang dapat diterima oleh setiap personil,tetapi juga sekaligus sebagi pemberian penghargaan kepada personil yang bersangkutan atas jerih payah pengabdiannya. Karena itulah kenaikan pangkat dapat mempunyai nilai motivatifyang tinggi. Kenaikan pangkat pegawai negeri sipil diberikan dengan ketentuan sebagai berikut;

1. 4 tahun dalam pangkat yang dimiliki dan setiap unsur DP3 sekurang-kurangnya memperoleh nilai baik dalam tahun terakhir

2. 5 tahun dalam pangkat yang dimiliki setiap unsur DP3 sekurang-kurangnya bernilai cukup dalam tahun terakhir.

Kenaikan pangkat merupakan suatu penghargaan bagi seorang pegawai yang juga merupakan salah satu bentuk dari promosi.

\section{B. Jenis-Jenis Kenaikan Pangkat:}

1. Kenaikan pangkat reguler Diberikan kepada pegawai yang telah memenuhi syarat yang telah ditentukan tanpa terikat pada jabatan yang dipangkunya

2. Kenaikan pangkat pilihan Diberikan epada pegawai yang telah memangku jabatan struktural atau fungsional, dalam batas-batas jenjang pangkat yang ditentukan untuk jabatan yang bersangkutan.

3. Kenaikan pangkat istimewa Diberikan kepada pegawai yang menunjukkan prestasi kerja yang luar biasa baiknya menemukan penemuan baru yang bermanfaat bagi negara.

4. Kenaikan pangkat pengabdian Sebagai penghargaan bagi pegawai yang akan mencapai batas usia pensiun dan akan mengakhiri masa jabatannya dengan hak pensiun.

5. Kenaikan pangkat anumerta Merupakan kenaikan pangkat setingkat lebih tinggi dari pada pangkat yang dimiiki, untuk menghargai pengabdian dan jasa-jasanya kepada negara dan bangsa.

6. Kenaikan pangkat dalam tugas belajar Diberikan dalam batas jenjang pangkat yang ditentukan untuk jabatan yang dipangku sebelum yang bersangkutan mengikuti pendidikan.

7. Kenaikan pangkat menjadi pejabat negara diberikan kepada pegawai yang diangkat menjadi pejabat negara, baik yang dibebaskan dari jabatan organiknya, maupun yang tidak dibebaskan dari jabatan organiknya.

8. Kenaikan pangkat dalam penugasan diluar instansi Dibrikan kepada pegawai yang dipekerjakan atau diperbantukan kepada instansi lain.

9. Kenaikan pangkat dalam wajib militer Diberikan kepada pegawai selama menjalani dinas wajib militer.

10. Kenaikan pangkat penyesuaian ijasah Diberikan keada pegawai yang telah menyelesaikan belajar sesuai dengan surat tanda tamat belajar yang diperolehnya.

\section{Evaluasi Kinerja PTK}

Penilaian/evaluasi adalah proses pengumpulan, pengolahan, analisis dan interpretasi data sebagai bahan pengambilan keputusan. Evaluasi diperlukan untuk mengetahui tingkatan suatu objek yang dievaluasi tersebut. Dalam konteks evaluasi guru /tenaga pendidik, yang menjadi objek evaluasi ialah guru/tenaga pendidik tersebut. Evaluasi tersebut menganalisis seberapa besar persentase kinerja guru dalam melaksanakan tugasnya.

Pada Peraturan Menteri Negara Pendayagunaan Aparatur Negara dan Reformasi Birokrasi No.16 Tahun 2009 mengatakan bahwa penilaian kinerja guru adalah penilaian yang dilakukan terhadap setiap butir kegiatan tugas utama guru dalam rangka pembinaan karir, kepangkatan, dan jabatannya. Evaluasi kinerja guru/tenaga pendidik merupakan sebuah system pengelolaan kinerja berbasis guru yang di buat untuk menilai mengevaluasi tingkat kinerja guru secara individu dalam rangka mencapai kinerja sekolah secara maksimal yang berdampak pada peningkatan prestasi pesertadidik.

Tujuan pelaksanaanya evaluasi kinerja guru/tenaga pendidik ialah sebagai berikut; 
1. Meningkatkan efisiensi dan efektivitas kinerja guru dan sekolah.

2. Menyajikan suatu landasan untuk pengambilan keputusan dalam mekanisme penetapan efektif atau kurang efektifnya kinerja guru.

3. Menyediakan landasan untuk program pengembangan keprofesian berkelanjutan bagi guru.

4. Menjamin bahwa guru melaksanakan tugas dan tanggung-jawabnya serta mempertahankan sikapsikap yang positif dalam mendukung pembelajaran peserta didik untuk mencapai prestasinya.

5. Menyediakan dasar dalam system peningkatan promosi dan karir guru serta bentuk penghargaan lainnya.

Dalam pelaksanaan evaluasi kinerja tenaga pendidik dibutuhkan adanya rambu-rambu/konsep evaluasi. Konsepe valuasi disini mencakup syarat system evaluasi, prinsip pelaksanaan, aspek yang dinilai dalam evaluasi dan perangkat pelaksanaan evaluasi. Menurut Marmoah (2018) syarat-syarat system evaluasi kinerja tenaga pendidik diperlukan untuk memperoleh hasil evaluasi yang benar dan tepat. Syarat-syarat tersebut antara lain;

1. Valid

Aspek yang dinilai benar-benar mengukur komponen-komponen tugas tenaga pendidik dalam melaksanakan pembelajaran, pembimbingan, dan/atau tugas lain yang relevan dengan fungsi

sekolah.

2. Reliable

Tingkat kepercayaan tinggi bila proses yang dilakukan memberikan hasil yang sama untuk seorang tenaga pendidik yang dievaluasi kinerjanya oleh siapapun dan kapan pun.

3. Praktis

Dapat dilakukan oleh siapa pun dengan relative mudah, dengan tingkat validitas dan reliabilitas yang sama dalam semua kondisi tanpa memerlukan persyaratan tambahan.

Prinsip-prinsip pelaksanaan evaluasi kinerja tenaga pendidik digunakan agar hasil pelaksanaan dan evaluasi kinerja tenaga pendidik dapat dipertanggung jawabkan. Adapun prinsip-prinsipnya diantaranya;

1. Berdasarkan ketentuan

Evaluasi kinerja tenaga pendidik harus dilaksanakan sesuai dengan prosedur dan mengacu pada peraturan yang berlaku.

2. Berdasarkan kinerja

Aspek yang dinilai dalam evaluasi kinerja tenaga pendidik adalah kinerja yang dapat diamati dan dipantau sesuai dengan tugas guru/tenaga pendidik sehari-hari dalam melaksanakan kegiatan pembelajaran, pembimbingan, dan/atau tugas tambahan yang relevan dengan fungsi sekolah/madrasah.
3. Berlandaskan dokumen PK Guru Penilai, guru/tenaga pendidik yang dinilai, dan unsur lain yang terlibat dalam proses evaluasi kinerja tenaga pendidik harus memahami semua dokumen yang terkait dengan sistem evaluasi kinerja tenaga pendidik, terutama yang berkaitan dengan pernyataan kompetensi dan indikator kinerjanya secara utuh, sehingga penilai, guru/tenaga pendidik dan unsur lain yang terlibat dalam proses evaluasi mengetahui dan memahami tentang aspek yang dinilai serta dasar dan kriteria yang digunakan dalam evaluasi.

4. Dilaksanakan secara konsisten

Dilaksanakan teratur setiap tahun diawali dengan penilaian formatif di awal tahun dan penilaian sumatif di akhir tahun Evaluasi Kinerja Tenaga Pendidik setidaknya dilaksanakan satu tahun sekali pada tiap sekolah. Evaluasi tersebut dilaksanakan oleh kepala sekolah atau orang/panitia yang ditunjuk/dibentuk langsung oleh kepala sekolah.

\section{Peran Guru Dalam Administrasi PTK}

Dalam administrasi kepegawaian lebih difokus kepada guru sebagai pegawai negeri. Pegawai negeri adalah mereka yang setelah memenuhi syarat-syarat yang ditentukan dalam perundang-undangan yang berlaku, diangkat oleh pejabat yang berwenang dan diserahi tugas dalam suatu jabatan negeri atau disertai tugas Negara lainnya yang ditetapkan berdasarkan suatu perundang-undangan yang berlaku. Seorang calon guru bisa menjadi seorang pegawai negeri jika telah melalui rekrutmen guru. Rekrutmen merupakan satu aktivitas manajemen yang mengupayakan dapatkannya seorang atau lebih calon pegawai yang betul-betul potensial untuk menduduki posisi tertentu atau melaksanakan tugas tertentu di sebuah lembaga.

Adapun peran guru dalam administrasi kepegawaian menurut Arikunto, dkk (2008) yaitu;

1. Membuat buku induk pegawai

2. Mempersiapkan usul kenaikan pangkat pegawai negeri, prajabatan, Karpeg, cuti pegawai,dan lainlain.

3.Membuat inventarisasi semua file kepegawaian, baik kepala sekolah, guru, maupun tenaga tata administrasi.

4.Membuat laporan rutin kepegawaian harian, mingguan, bulanan, dan tahunan.

5. Membuat laporan data sekolah dan pegawai.

6. Mencatat tenaga pendidik yang akan mengikuti penataran.

7. Mempersipkan surat keputusan Kepala Sekolah tentang proses KBM, surat tugas, surat kuasa, dan lain - lain. 


\section{KESIMPULAN}

1. Evaluasi kinerja tenaga pendidik harus dilaksanakan sesuai dengan prosedur dan mengacu pada peraturan yang berlaku.

2. Aspek yang dinilai dalam evaluasi kinerja tenaga pendidik adalah kinerja yang dapat diamati dan dipantau sesuai dengan tugas guru/tenaga pendidik sehari-hari dalam melaksanakan kegiatan pembelajaran, pembimbingan, dan/atau tugas tambahan yang relevan dengan fungsi sekolah/madrasah.

\section{DAFTAR}

Arikunto, Suharsimi, \& L. Y. (2008). Manajemen pendidikan. Yogyakarta: Aditya Media dan FIP UNY.

Marmoah, S. (2018). adminitrasi dan supervisi pendidikan teori dan praktek (2nd ed.).

Yogyakarta: deepublish.

Nawawi, H. (1994). Administrasi Pendidikan. Jakarta: Ghalia Indonesia.

Purwanto, N. (2007). Administrasi Pendidikan. Bandung: Suka Jaya 